\title{
Holiday Sunshine in the British Isles*
}

$\mathrm{I}^{\mathrm{N}}$ the absence of any long-range forecasts, made along strictly scientific lines, as to the occurrence of sunny periods during the year, the accumulated statisties of past sunshine records warrant a special study. They serve as a guide to the average conditions for any season. Although few are fortunate enough to select the time for their holidays, all have some choice in the matter of locality. Sunshine, in these days especially, may be regarded as the most important meteorological requirement for an enjoyable holiday.

The data are described as referring to bright sunshine because a certain intensity is required before the recorder will register. The standard instrument of the meteorologist for recording sunshine is of the Campbell-Stokes pattern, in which the duration of sunshine is recorded in the form of a scorched or burnt line, traced on a graduated card by means of a spherical lens acting as a burning glass. The instrument was first introduced by Mr. J. F. Campbell in 1853 at the Office of the Board of Health in Whitehall, and afterwards modified by Sir George Stokes to receive a strip of cardboard on which to record the focused rays of the sun. Records from these instruments were first published in 1880, and the number of climatological stations reporting to the Meteorological Office has steadily increased, so that in 1934 it was possible to publish averages of bright sunshine for 171 stations in the British Isles for periods ending 1930, usually 1901-30. Naturally, the stations are more numerous in the south of England and fewest in the relatively uninhabited mountainous regions. In many districts the distribution has had to be inferred from records outside these areas. This renders all the more important the record maintained at Ben Nevis Observatory, at an altitude of 4,400 ft., during the years 1891-1902 for which the mean values in hours were : J. $0.64 ;$ F. 1.61 ; M. 2.06 ; A. 2.88 ; M. 4.27 ; J. 4.14 ; J. 2.95 ; A. $2 \cdot 00$; S. 1.91 ; 0. 1.58 ; N. 1.02 ; D. 0.55 ; Year 2.13 . Actually this station is probably the least sunny in the whole of western Europe. The frequency of cloud is confirmed by the fact that those climbing to the summit are but infrequently rewarded by a good view.

It is well known that the average amount of sunshine tends to decrease from south to north and from the coast inland. Before considering the distribution of bright sunshine over the country

* The information in this article is based on a paper on "The distribution over the British Isles of the average duration of bright sunshine : monthy and annual maps and statistics", by Dr. J Meteorological Society for April 1936. generally, and from month to month, it seems desirable to define the total possible duration. The duration of possible sunshine is referred to as the interval between the ascending and descending transits of the centre of the sun's disk across the horizon, as actually seen. The mean daily duration of possible sunshine is set out in Table 1 for each month of the year for latitudes $50^{\circ}, 52^{\circ}, 54^{\circ}, 56^{\circ}$, $58^{\circ}$ and $60^{\circ} \mathrm{N}$. Latitude $50^{\circ}$ corresponds roughly with the Lizard; $52^{\circ}$ with Valentia, Cork, Fishguard, Hereford, Buckingham and Felixstowe; $54^{\circ}$ with Blacksod Point, Greenore, Morecambe and York; $56^{\circ}$ with Helensburgh and Leith; $58^{\circ}$ with the south of Lewis and Lairg ; and $60^{\circ}$ with the south of the Shetland Islands. The statistics show that at mid-summer the possible duration of sunshine in the north of Scotland is about two hours greater, and at mid-winter nearly two hours less than that in the south of England. On the other hand, there is very little difference with latitude for both March and September.

Table 1.-Daily mean duration of possible sunshine.

\begin{tabular}{|c|c|c|c|c|c|c|c|}
\hline \multirow{2}{*}{ Month } & & \multicolumn{6}{|c|}{ Latitude (North) } \\
\hline & & $50^{\circ}$ & $52^{\circ}$ & $54^{\circ}$ & $56^{\circ}$ & $58^{\circ}$ & $60^{\circ}$ \\
\hline $\begin{array}{l}\text { January } \\
\text { February } \\
\text { March ... } \\
\text { April ... } \\
\text { May ... } \\
\text { June ... } \\
\text { July ... } \\
\text { August } \\
\text { September } \\
\text { October } \\
\text { November } \\
\text { December }\end{array}$ & $\begin{array}{l}\ldots \\
\ldots \\
\ldots \\
\ldots \\
\ldots \\
\ldots \\
\ldots \\
\ldots \\
\ldots \\
\ldots \\
\ldots \\
\ldots\end{array}$ & $\begin{array}{r}\mathrm{hr} . \\
8 \cdot 6 \\
10 \cdot 0 \\
11 \cdot 8 \\
13 \cdot 7 \\
15 \cdot 3 \\
16 \cdot 2 \\
15 \cdot 8 \\
14 \cdot 4 \\
12 \cdot 6 \\
10.7 \\
9 \cdot 0 \\
8.1\end{array}$ & $\begin{array}{r}\text { hr. } \\
8 \cdot 3 \\
9 \cdot 9 \\
11 \cdot 8 \\
13 \cdot 8 \\
15 \cdot 6 \\
16 \cdot 6 \\
16 \cdot 1 \\
14 \cdot 6 \\
12 \cdot 6 \\
10 \cdot 6 \\
8 \cdot 8 \\
7 \cdot 8\end{array}$ & $\begin{array}{r}\text { hr. } \\
7 \cdot 9 \\
9 \cdot 7 \\
11 \cdot 8 \\
14 \cdot 0 \\
15 \cdot 9 \\
17 \cdot 0 \\
16 \cdot 5 \\
14 \cdot 8 \\
12 \cdot 7 \\
10 \cdot 5 \\
8 \cdot 5 \\
7 \cdot 4\end{array}$ & $\begin{array}{r}\text { hr. } \\
7 \cdot 6 \\
9 \cdot 5 \\
11 \cdot 7 \\
14 \cdot 1 \\
16 \cdot 2 \\
17 \cdot 4 \\
16 \cdot 9 \\
15 \cdot 0 \\
12 \cdot 7 \\
10 \cdot 4 \\
8 \cdot 2 \\
7.0\end{array}$ & $\begin{array}{r}\text { hr. } \\
7 \cdot 2 \\
9 \cdot 3 \\
11 \cdot 7 \\
14 \cdot 3 \\
16 \cdot 8 \\
17 \cdot 9 \\
17 \cdot 3 \\
15 \cdot 3 \\
12 \cdot 8 \\
10 \cdot 3 \\
7 \cdot 9 \\
6 \cdot 5\end{array}$ & $\begin{array}{r}h r . \\
6.7 \\
9.0 \\
11.7 \\
14.5 \\
17.0 \\
18.6 \\
17.9 \\
15.6 \\
12.9 \\
10.1 \\
7.5 \\
5.9\end{array}$ \\
\hline Year ... & $\ldots$ & $12 \cdot 20$ & $12 \cdot 22$ & $12 \cdot 23$ & $12 \cdot 25$ & $12 \cdot 27$ & $12 \cdot 30$ \\
\hline
\end{tabular}

The most convenient procedure, in the case of the British Isles, is to consider each average value of bright sunshine as a percentage of the possible duration. So far as the annual values are con. cerned the largest percentages $(40$ per cent or more) occur along parts of the south and southeast coasts of England, including the neighbourhood of Torquay, from Weymouth to Dungeness, most of the Isle of Wight as well as near Margate and Felixstowe. Stations in Jersey and Guernsey report 42 per cent, and as much as 41 per cont occurs at Bognor Regis, Eastbourne, Worthing and Sandown. The area with more than 35 por cent extends along the west coast to include parts of the Isle of Man and Anglesey and the neighbour. hood of Llandudno, and along the east cosst almost to the Humber. Less than 30 per cont occurs over a large area stretching northwards from central Wales and the Midlands to include 
most of Scotland, apart from coastal districts south of the Isle of Skye on the west and Aberdeen on the east. The island of Tiree gives the surprisingly high value of 35 per cent and Lossiemouth, on the Moray Firth, as much as 30 per cent. Over the mountainous districts of central and northern Scotland bright sunshine occurs on only 20-25 per cent of the possible duration. Over Ireland the range is small, being from 35 per cent in the extreme south-west to 28 per cent in the north-west. The smallest values in England, of just less than 25 per cent, occur in certain industrial areas of the Midlands. In the suburbs of London bright sunshine occurs on about one-third of the total possible time and this proportion is experienced in coastal districts as far north as Morecambe, parts of the Isle of Man and Spurn Head, and also in certain of the flatter islands to the south-west of Scotland, such as Tiree.

The distribution over the country for each month is similar to that shown on the annual map so far as the localities of much or little sunshine is concerned. The actual values increase steadily, however, from December until April, May or June. The minimum percentage occurs at most stations in December, although a few give similar percentages in December and January, such as Armagh in Northern Ireland, Torquay and Durham. There is less than 10 per cent in the neighbourhood of the manufacturing towns near Manchester, and in the mountainous districts of the north-west of Scotland in both January and December. On the other hand, percentages of 45 per cent and more occur in six months. Such percentages occur as early as April along the coasts of Cornwall and south Devon and at isolated coastal stations in the south-east, and in May, June, July, August and September along most of the south and southeast coasts from Torquay to Lowestoft. Percent. ages of $\mathbf{4 5}$ or more also occur in April and May in Tiree. They cover the largest part of the British Isles in May. In June these values also occur in the neighbourhood of the Severn Estuary. In May the average amounts of bright sunshine reach half the possible duration, when they are confined to a few coastal stations in the extreme south-east of England from Eastbourne to Felixstowe.

The sunniest month of the year is either April, May or June over practically the whole of the British Isles. April is the sunniest month in the Outer Hebrides, in the neighbourhood of Loch Ness, near Aberdeen, and the extreme south of Cornwall. May is the sunniest month from Mull to northern Aberdeenshire, in the south-west of Scotland, in the south-west of Ireland, near Aberystwyth and over most of the south-eastern half of England. June is the sunniest month over central and southeastern Scotland, the south-east of Ireland, and most of the north-western half of England and Wales. July nowhere gives the largest percentage values for the year (although in the neighbourhood of London July ranks as the sunniest month in actual hours). August is the sunniest month only at Lowestoft and in Jersey and Guernsey, but it ranks with May at Greenwich. Most stations show a fairly simple increase in the percentage values from December to the early summer months, but there is a subsidiary maximum in August in parts of the south-east of England and the Midlands, and a subsidiary maximum in September over most of Scotland, the north-west of England and Ireland. At Newquay there is little difference in the percentage sunshine for April, May and June, and at Torquay between May, June and July.

Table 2.-Average General Sunshine, 1901-30, as percentages of possible.

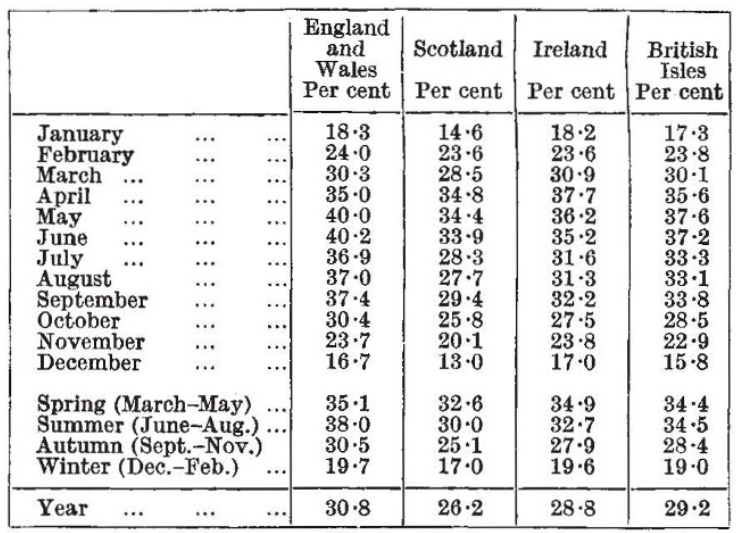

The average general values for the months and the seasons are given in Table 2 for England and Wales, Scotland, Ireland and the British Isles as a whole. The table emphasises the large values for the bright sunshine in both Scotland and Ireland in April and the appreciably greater sunshine of May than of either July or August over England and Wales.

So far as the total amounts of bright sunshine are concerned, there are therefore obvious advantages in early holidays. Along the east and south coasts, from Scarborough to the Isle of Wight, May has advantages, while along the west and south-west coasts of England June is to be preferred. For holidays in April the records suggest the neighbourhood of Penzance and the Seilly Isles, and in August the Channel Isles. In the English Lake District the choice would fall to May, June or September, before July or August. For a visit to the islands of the south-west of Scotland there are advantages in selecting April or May.

On the average, the sunniest month of the year occurs six months after the least sunny month over a broad strip across central districts of Great Britain. Both to the north-west and south-east 
the sunniest month occurs earlier. There is a marked tendency therefore in many localities for the summer to come upon us relatively quickly and for winter to be longer delayed.

It must be admitted that sunshine is only one meteorological factor to be considered in the selection of the best time and locality for holidays. Attention must also be paid to the frequency of rainfall, air temperature and sea temperature. For this reason the procedure adopted in the Hand- book of the British Health Resorts Association is a particularly happy one, for it gives the meteorological statistics of each health resort, together with comments on the climate from a medical aspect. It is a comforting fact, however, that in all parts of the British Isles the average annual duration of sunshine exceeds that of recordable rainfall, and that in the south-east of England the duration of sunshine is as much as seven times greater than that of recordable rain.

\section{Percy Sladen Expedition to Lake Huleh}

\section{By Roger Washbourn and R. F, Jones}

$\mathrm{T}$ HE Percy Sladen Expedition to Lake Huleh, Palestine, consisting of the present writers, has now returned. Biological investigations have been carried out during the greater part of the period August-December 1935. While much work remains to be done in the sorting and identification of the material, it is nevertheless felt that a preliminary account of the work may be of interest.

As stated in NATURE of October 5, 1935, p. 538, the region called the Huleh comprises two parts, which differ considerably (Fig. 1). The lake is at the southern end of the broad Huleh valley, and is separated from Tiberias by a low range of hills. It is bounded on the northern side by the swamp, which is for the most part an impenetrable tangle of papyrus, but which also contains channels of running water, and pools which may be up to an acre or so in extent. The lake covers approximately 5 square miles, and is of a general depth of 4-6 ft., with occasional deeper holes.

The lake shore is of gravel, where winter-running wadis have brought down much material from the surrounding hills, and where the direction of wave action keeps the stones clear from mud. In quiet places, under the shelter of the gravel spits, the shore is of mud, which in places becomes colonised by Phragmites. The bottom of the lake is everywhere of a light greyish mud. This mud is colonised by a great mass of aquatic plants, the stems of which may reach the surface of the water. The chief types present are species of Myriophyllum, Potomogeton, and Nuphar. They occur in large consociations, some of which are practically pure communities of a single species.

The water of the lake is fresh to the taste (accurate analyses of the chemical composition are being made), and the temperature is usually high. Fluctuations in temperature must be considerable; on one occasion the thermometer was observed to rise from $29^{\circ}$ to $31 \cdot 4^{\circ} \mathrm{C}$. in approximately $2 \frac{1}{4}$ hours.
The water is alkaline ; the $p \mathrm{H}$ being approximately 7.8-8.0 during the daytime. The oxygen content was found to be high, and the carbon dioxide content comparatively low.

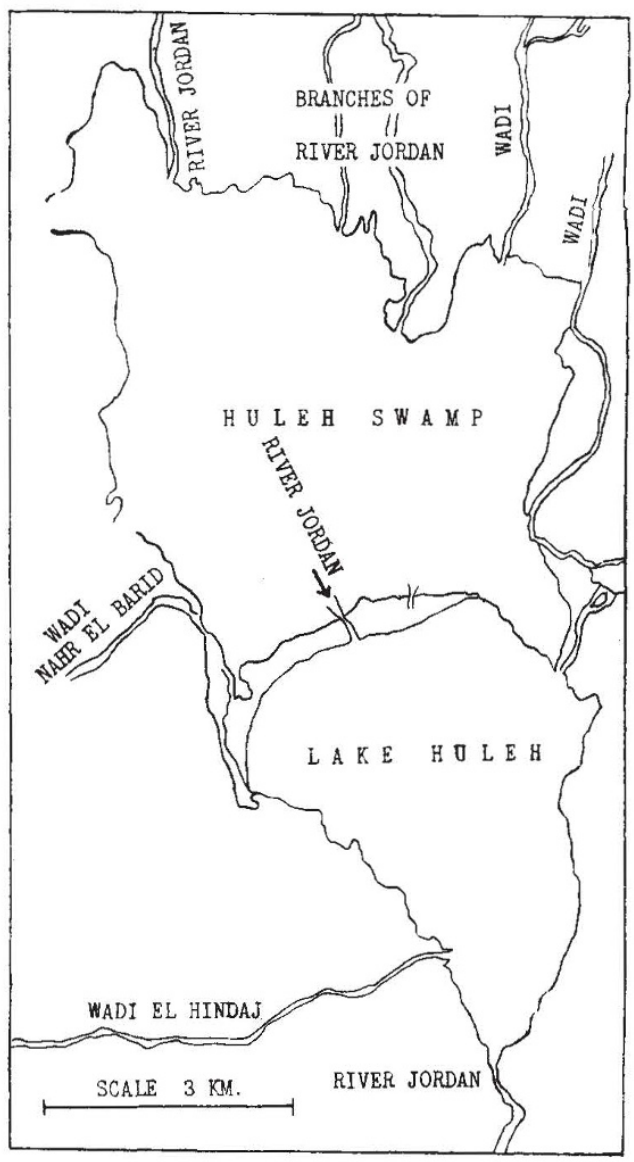

Fig. 1.

The phytoplankton was exceedingly dense, and was probably responsible largely for the constant colour of the lake water. The animal plankton on the other hand was meagre, and by no means 